\title{
EFFICIENCY OF INTERNAL STRENGTHENING R.C BEAMS WITH RECTANGULAR OPENINGS IN SHEAR ZONE BY USING STEEL PLATES
}

Nageh M. Ali ${ }^{1}$

${ }^{1}$ Demonstrator, Civil Eng. Dept., Assiut University

Mohamed M. Ahmed ${ }^{2}$

${ }^{2}$ Associate Professor of Structural Eng., Civil Eng. Dept., Assiut University

Mohamed Farag A. ${ }^{3}$

${ }^{3}$ Professor of Structural Eng., Civil Eng. Dept., Assiut University

Abd Elrahman Megahid ${ }^{4}$

${ }^{4}$ Professor of Structural Eng, Civil Eng. Dept., Assiut University.

(Received May 11, 2010 Accepted May 27, 2010).

The provision of transverse openings in floor beams to facilitate the passage of utility pipes and service ducts results not only in a more systematic layout of pipes and ducts; but also translates into substantial economic savings in the construction of a multi-storey building. Over the past several decades, many researchers exerted great efforts to predict and interpret the behavior of beams with web openings [3-9]. They recommended convenient methods for the design of such beams. External strengthening by using external steel plates or external CFRP laminates will be a satisfactory method in the case if it is required to provide new opening in existing beams. In this research it was suggested to use internal steel plates to improve the efficiency of beams with opening. Therefore, twelve R.C beams were tested under static loading up to failure; eleven of them were fabricated with rectangular opening through the web in shear zone while the remaining beam had a solid web. Internal steel plates around the opening were used in strengthening them. The effect of internal steel plate's thickness, and configuration, horizontal steel plate length and concrete grade is investigated. The pattern of cracks and modes of failure were observed. The mid span deflection, the inner edge of opening deflection and the difference between deflections of the two opening edges were measured. The crack and ultimate load were recorded. The results were studied and given in shape of plates, tables and curves.

KEYWORDS: perforated R.C Beams, concrete strength, pattern of cracks, deflections, steel plates and strengthening of web openings

\section{INTRODUCTION}

The trend in recent years toward the systems approach to building has generated a need for web openings in structural members. Web openings provide a passageway for ducts and pipes of air conditioning, water supply, sewage, and other electrical and mechanical services. Passing these services through openings in the webs of the floor 
beams eliminates a significant amount of dead space and results in a more compact and more economical design. For sure, web openings have a minus effect on both strength and the stiffness of the beams, so these beams must be checked and adequately reinforced to eliminate the weakness.

In 1985, Mansur et-al [4] used a rational design method for reinforced concrete beams with large rectangular opening that are subject to bending moment and shear force. In 1985, Nassef, et-al [7] studied the effect of openings located in the shear zones on the behavior of reinforced concrete beams. In 1998, Mansur [5] studied the effect of introducing a transverse opening on the behaviour and strength of reinforced concrete beams under predominant shear on the basis of observed structural response. Okasha [3] in 2000 studied the effect of CFRP in strengthening and improving the behavior of beams with openings. In 2001, Mansur, et-al. [6] investigate the design of reinforced concrete beams with circular openings. In 2002 Carina N., Martina S.H. [8] studied the behaviour of R.C beams with large openings in shear zone, In 2007. AbdelShafy [9] studied the effect of opening dimensions and positions on the static behaviour of high strength R.C perforated beams.

In the current thesis, an experimental study for web openings strengthened internally with steel plates will be presented, the main object of this thesis is to study the availability of providing rectangular web openings in R.C beams with smallest minus effect on both strength and stiffness by means of strengthening openings with internal steel plates.

The mean parameters taken into considerations are:

- Configuration of used steel plates around opening.

- Dimensions of top and bottom steel plates (thickness and length), and

- Concrete grade.

\section{EXPERIMENTAL PROGRAM}

Twelve reinforced concrete beams with rectangular cross-section were prepared. The first beam was a solid one with no openings and served as a reference beam. Each one of the rest beams had a rectangular web opening of $30 \mathrm{~cm}$ length and $12 \mathrm{~cm}$ height at a distance from the nearest support to its center equals to half its shear span, ten beams of them were strengthened internally by using steel plates around the opening in form of four groups. In group (A), beams ( $\mathrm{RO} 3, \mathrm{RO} 4$ and $\mathrm{RO}$ ), were provided with the same internal steel plates length $\left(\mathrm{L}_{\mathrm{h}}\right)$, width $\left(\mathrm{W}_{\mathrm{h}}\right)$ and configuration type. The only variable parameter was the thickness of the internal steel plates $\left(\mathrm{t}_{\mathrm{h}}\right)$. It had the values 3 , 2 and $4 \mathrm{~mm}$ respectively. In Group (B), beams (RO3 and RO6), the only variable parameter was the configuration type of the internal steel plates in form of type (1) and type (2) respectively. See Fig. (2). Group (C), consists of two series (C1 and C2). In series $\mathrm{C} 1$, beams (RO7 and RO8), and taking beam (RO3) into consideration, the only variable parameter was the internal steel plate's length $\left(\mathrm{L}_{\mathrm{h}}\right)$. It had the values 50, 40 and $60 \mathrm{~cm}$ for such group respectively. Series C2, beams (RO9 and RO10) was similar to series $\mathrm{C} 1$ except the configuration type of the internal steel plates. The configuration type of the internal steel plates of series $\mathrm{C} 2$ was type2. Also taking beam (RO6) into consideration the only variable parameter was the internal steel plate's length $\left(\mathrm{L}_{\mathrm{h}}\right)$. It had values 50,40 and $60 \mathrm{~cm}$ for such group respectively. Group (D), includes beams (RO3, RO11and RO12), the only variable parameter was the grade of concrete $\left(f_{c u}\right)$. It 
had values 30, 60 and 80 MPA respectively.

All the tested beams have the same total length of $1.45 \mathrm{~m}$ and over all depth and width of $30 \mathrm{~cm}$ and $12 \mathrm{~cm}$ respectively. They were simply supported on a span $1.30 \mathrm{~m}$ apart. All beams were tested under one point static loading at mid span with shear span to depth ratio $(\mathrm{a} / \mathrm{d})$ of 2.4. Steel reinforcement of all beams was:

- Four bars $16 \mathrm{~mm}$ diameter as tension reinforcement.

Two bars $12 \mathrm{~mm}$ diameter as compression reinforcement.

- $\quad$ Stirrups $6 \mathrm{~mm}$ diameter with $14 \mathrm{~cm}$ spacing along the solid parts.

- Each vertical side of the opening was reinforced by means of one closed stirrups $6 \mathrm{~mm}$ diameter.

- $\quad$ Both top and bottom chords of opening length were reinforced by means of 4 closed stirrups of $6 \mathrm{~mm}$ diameter.

Details of all tested beams are shown in Table (1).

Where

Config. $=$ configuration type of steel plates. (Type 1 and type $2=$ see details in Fig. (2)).

$\mu \mathrm{o} \%=$ confinement ratio (Volume of steel plates / volume of confined concrete)

Table. (1) Details of the Tested Beams

\begin{tabular}{|c|c|c|c|c|c|c|c|c|c|c|c|c|}
\hline \multirow{3}{*}{$\begin{array}{l}\dot{0} \\
Z \\
0 \\
0 \\
0 \\
0\end{array}$} & & \multirow{3}{*}{ 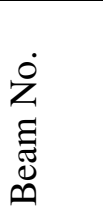 } & \multirow{3}{*}{ 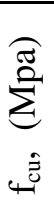 } & \multicolumn{7}{|c|}{$\begin{array}{c}\text { Internal Steel plates } \\
(\mathrm{cm})\end{array}$} & \multirow{3}{*}{$\begin{array}{l}0^{2} \\
\frac{0}{2}\end{array}$} & \multirow{3}{*}{ 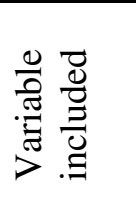 } \\
\hline & & & & \multicolumn{3}{|c|}{ horizontal } & \multicolumn{3}{|c|}{ vertical } & \multirow[t]{2}{*}{ Config. } & & \\
\hline & & & & $\mathrm{L}_{\mathrm{h}}$ & $\mathrm{W}_{\mathrm{h}}$ & $t_{h}$ & $\mathrm{~L}_{\mathrm{v}}$ & $\mathrm{W}_{\mathrm{v}}$ & $\mathrm{t}_{\mathrm{v}}$ & & & \\
\hline \multirow{2}{*}{\multicolumn{2}{|c|}{$\mathrm{R}$}} & SB1 & 30 & -- & --- & --- & --- & --- & --- & --- & --- & \multirow[b]{2}{*}{ Ref. } \\
\hline & & $\mathrm{UO} 2$ & 30 & -- & --- & --- & --- & --- & --- & --- & --- & \\
\hline \multirow{3}{*}{\multicolumn{2}{|c|}{ A }} & RO3 & 30 & 50 & 5.0 & 0.3 & --- & --- & --- & Type1 & 2.78 & \multirow{3}{*}{ 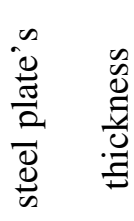 } \\
\hline & & RO4 & 30 & 50 & 5.0 & 0.2 & --- & --- & --- & Type1 & 1.85 & \\
\hline & & RO5 & 30 & 50 & 5.0 & 0.4 & --- & --- & --- & Type1 & 3.7 & \\
\hline \multicolumn{2}{|c|}{ B } & RO6 & 30 & 50 & 5.0 & 0.3 & 25 & 5.0 & 0.3 & Type2 & 3.68 & 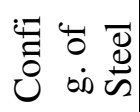 \\
\hline \multirow{4}{*}{$\mathrm{C}$} & \multirow{2}{*}{$\mathrm{C} 1$} & RO7 & 30 & 40 & 5.0 & 0.3 & --- & --- & --- & Type1 & 2.78 & \multirow{4}{*}{ 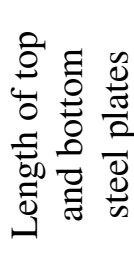 } \\
\hline & & RO8 & 30 & 60 & 5.0 & 0.3 & --- & --- & --- & Type1 & 2.78 & \\
\hline & \multirow[t]{2}{*}{$\mathrm{C} 2$} & RO9 & 30 & 40 & 5.0 & 0.3 & 25 & 5.0 & 0.3 & Type2 & 3.87 & \\
\hline & & RO10 & 30 & 60 & 5.0 & 0.3 & 25 & 5.0 & 0.3 & Type2 & 3.54 & \\
\hline \multirow{2}{*}{\multicolumn{2}{|c|}{ D }} & RO11 & 60 & 50 & 5.0 & 0.3 & --- & $\begin{array}{l}-- \\
\end{array}$ & --- & Type1 & 2.78 & \multirow{2}{*}{ 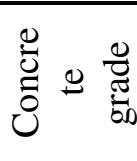 } \\
\hline & & RO12 & 80 & 50 & 5.0 & 0.3 & --- & --- & --- & Type1 & 2.78 & \\
\hline
\end{tabular}




\section{MATERIALS}

Three concrete mixes were designed to produce concrete having a 28 days cube compressive strength of about 30, 60 and $80 \mathrm{Mpa}$.

For normal strength concrete $\mathrm{f}_{\mathrm{cu}}$ of $30 \mathrm{Mpa}$, the constituent materials were:

a) Ordinary Portland cement. Its properties are according to E.S.S. [2].

b) Local sand was used, 2.60 specific gravity, $1.58 \mathrm{t} / \mathrm{m}^{3}$ volume weight and 2.59 fineness modulus.

c) Local gravel was used, 2.66 specific gravity, $1.7 \mathrm{t} / \mathrm{m}^{3}$ volume weight, 6.42 fineness modulus and $20 \mathrm{~mm}$ maximum nominal size.

d) Drinking water was used for both mixing and curing.

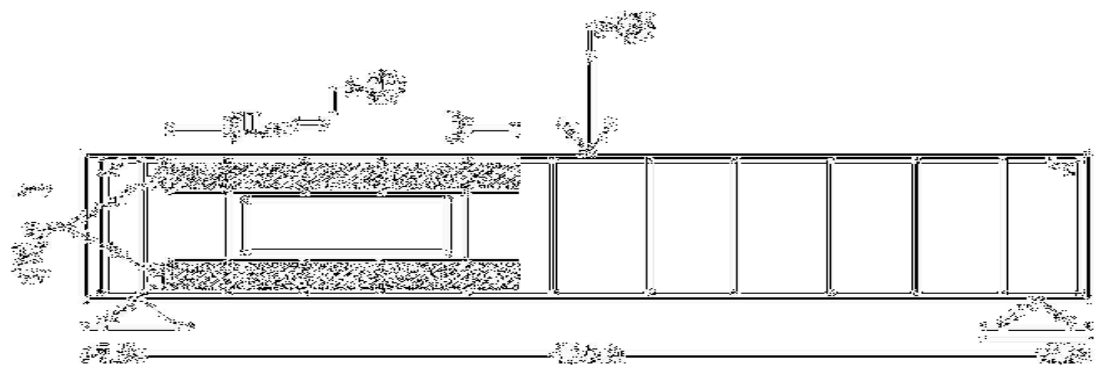

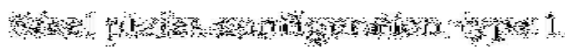
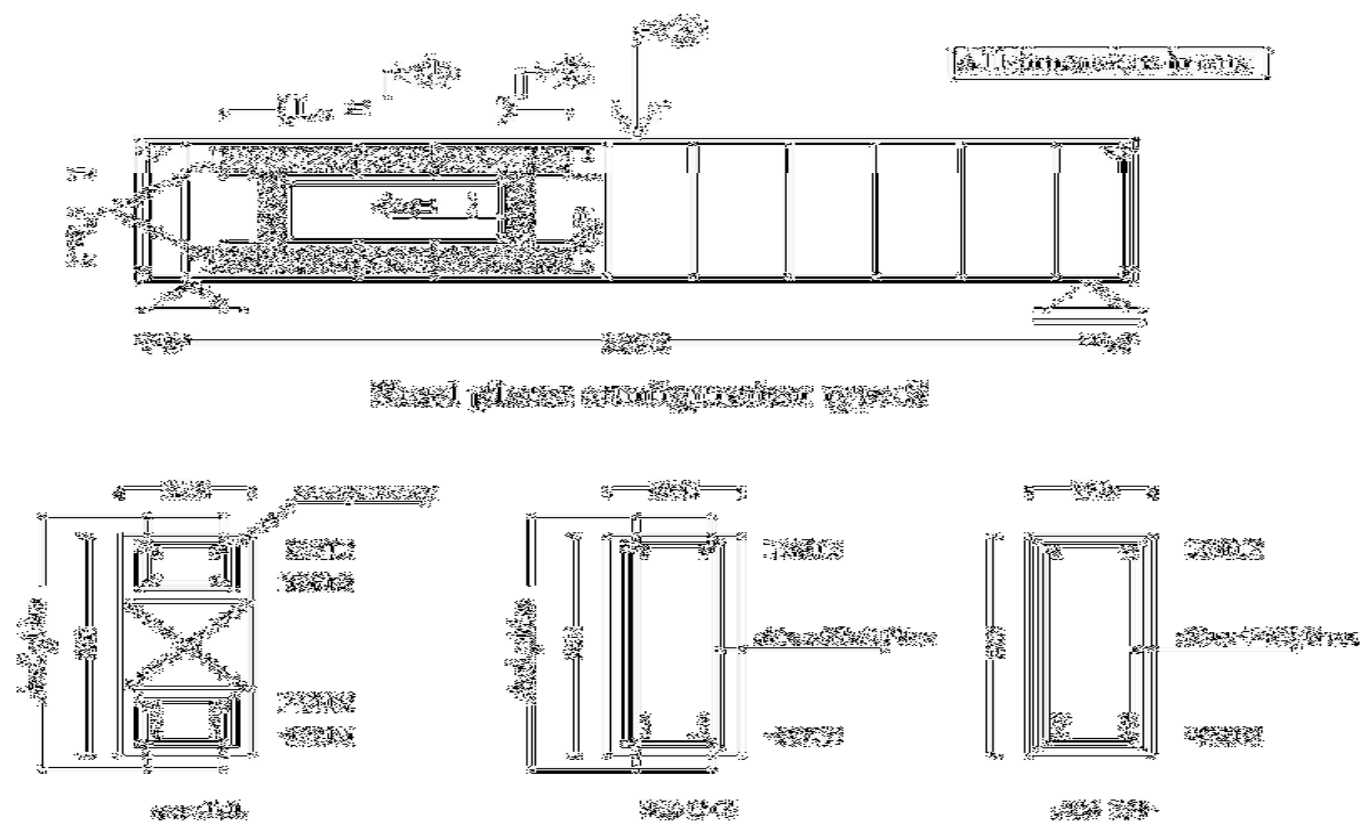

Fig. (2) Details of tested beams

For high-strength concrete $\mathrm{f}_{\mathrm{cu}}$ of 60 and $80 \mathrm{Mpa}$, the constituent materials were:

a) Cement, Sand and water were the same types and qualities that used in normal strength concrete mixes. 
b) Crushed basalt; the used crushed basalt was $20 \mathrm{~mm}$ maximum nominal size, 2.70 specific gravity and $2.35 \mathrm{t} / \mathrm{m}^{3}$ volume weight

c) Superplastisizer; the used additive was SIKAMENT (NN) produced by SIKA Industries Co. for SIKA Egypt Co., having a density $1.2 \mathrm{t} / \mathrm{m}^{3}$.

d) Silica fume, the specific surface area is $\left(12-15 \mathrm{~m}^{2} / \mathrm{g}\right)$ and the specific gravity is 2.2 .

The amounts of the constituent materials used in each mix by weight $\left(\mathrm{kg} / \mathrm{m}^{3}\right)$ are given in table (2).

The mechanical properties of the used steel plates were presented in table (3).

Table (2): Amounts of the Constituent Materials by Weight Required for One Cubic Meter of Concrete for the Used Different Mixes.

\begin{tabular}{|c|c|c|c|c|c|c|c|c|}
\hline \multirow{3}{*}{$\begin{array}{l}\text { Mix } \\
\text { No. }\end{array}$} & \multicolumn{7}{|c|}{ Amount of constituent materials/m3 } & \multirow{3}{*}{$\begin{array}{c}f_{c u} \\
\mathbf{M p} \\
\mathbf{a}\end{array}$} \\
\hline & \multirow{2}{*}{$\begin{array}{c}\text { Cement } \\
\text { (kg) }\end{array}$} & \multirow{2}{*}{$\begin{array}{c}\text { Sand } \\
(\mathrm{kg})\end{array}$} & \multicolumn{2}{|c|}{ Coarse aggr. (kg) } & \multirow{2}{*}{$\begin{array}{l}\text { Water } \\
\text { (litre) }\end{array}$} & \multirow{2}{*}{$\begin{array}{c}\text { Silica } \\
\text { fume }((\mathrm{kg})\end{array}$} & \multirow{2}{*}{$\begin{array}{c}\text { Add } \\
\cdot \\
.(\mathrm{kg}) \\
\end{array}$} & \\
\hline & & & Gravel & Broken Bazalt & & & & \\
\hline 1 & 400 & 620 & 1220 & ----- & 190 & ---- & ---- & 30 \\
\hline 2 & 450 & 600 & --- & 1200 & 155 & 70 & 15 & 60 \\
\hline 3 & 500 & 600 & -- & 1200 & 145 & 80 & 20 & 80 \\
\hline
\end{tabular}

Table (3): Mechanical Properties of the Used Steel Plates.

\begin{tabular}{|l|c|c|c|}
\hline Commercial thickness $(\mathrm{mm})$ & 4 & 3 & 2 \\
\hline Actual thickness $(\mathrm{mm})$ & 4.2 & 3.1 & 2.1 \\
\hline Yield strength $\left(\mathrm{kg} / \mathrm{cm}^{2}\right)$ & 2525 & 2402 & 2461 \\
\hline Ultimate strength $\left(\mathrm{kg} / \mathrm{cm}^{2}\right)$ & 3527 & 3700 & 3516 \\
\hline$\%$ of elongation & 27.1 & 28.3 & 29.1 \\
\hline
\end{tabular}

\section{FABRICATION OF THE TESTED BEAMS}

This program was carried out in reinforced concrete laboratory, Assiut University. The concrete was mixed by means of horizontal pan mixer of $0.1 \mathrm{~m}^{3}$ capacity. Concrete was placed in a steel forms. The openings were achieved using wooden parts of the same opening size. Concrete was compacted by electrical internal vibrator. Control specimens including three cubes $15 \mathrm{~cm}$ side length were cast with each beam at the same time. The beams and cubes were cured in the same manner.

\section{TEST PROCEDURE}

The beams were tested under one point static loading on increments. Before cracking load each increment was 0.5 ton but after cracking, each increment was 1.0 ton. The load was kept constant between two successive increments for about five minutes. During this period, reading of dial gauges and the crack propagation were recorded. At the same day, three control cubes were tested in compression. 


\section{TEST RESULTS}

\section{i- Pattern of Cracks and Mode of Failure of Tested Beams:}

In reference beam (SB1) which was a solid one the first crack was initiated at the bottom surface under point of load application (in mid-span). This crack grew very slowly vertically up to a distance more than three quarter of the height of the beam. With increasing the load, diagonal tension cracks formed between the point of load application and the support, the major crack was formed with an inclination ranges between $35^{\circ}$ and $47^{\circ}$ to the horizontal. The final mode of failure was shear failure accompanied with concrete crushing adjacent to the load application. In reference beam (UO2), without internal strengthening, the first crack was initiated at the top corner at inner edge of the opening. At this time small cracks formed at opposite opening corner. By load increasing, other cracks initiated in top chord and grew in length and width, near failure few cracks appeared in bottom chord. The major crack leading to failure was occurring in the top chord with an inclination to horizontal of about $20^{\circ}$. The final mode of failure was shear at opening. For all beams with strengthened opening, the first crack appeared in top chord at high moment end of the opening. Almost, at the same load small cracks appeared in bottom chord at low moment end of opening. After that, vertical cracks at bottom chord at the inner edge of the opening were observed. By load increasing further other cracks at inner side of the opening initiated and grew in length towards the point of loading. At outer side of the opening cracks propagated towards the nearest support. At later stage of loading diagonal cracks initiated at the solid side of the beam, in addition to small cracks near the center of the beam. Few minutes before failure small horizontal cracks were appeared in the middle of top chord, then diagonal cracks at top and bottom chords appeared suddenly accompanied with failure occurrence. Concrete crushing was occurred near point of loading. The mode of failure of these beams was due to shear at opening region. At failure the compression chord of the opening of these beams have been splitted diagonally with crushing of concrete at the high moment end. See Fig. (3).

In general, it can be seen that, crack number of the beam having opening without internal strengthening were smaller than those in beams having strengthened opening. The inclination of the major cracks of beams with strengthened opening was closed to horizontal compared with those of beams having opening without strengthening. The mode of failure of either beams having strengthened opening or beam having opening without strengthening was shear at opening region. Meanwhile, the failure of beams having strengthened opening was accompanied with concrete crushing at the point of load application and at the inner edge of the opening.

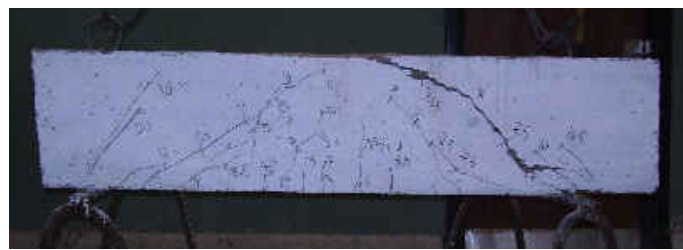

(1) Beam SB1

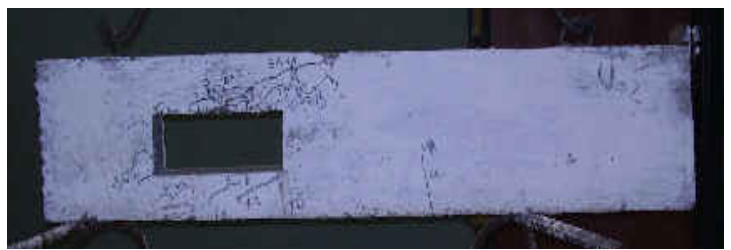

(2)Beam UO2 


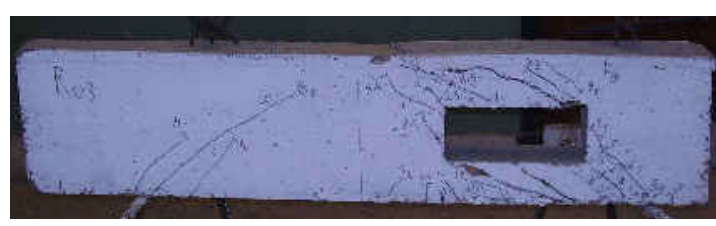

(3)Beam RO3

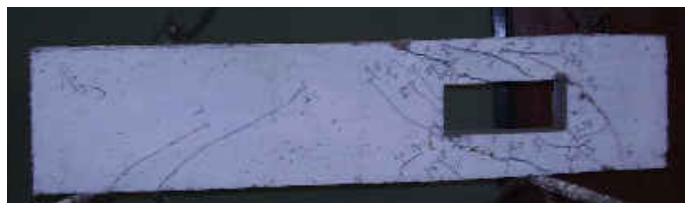

(5) Beam RO5

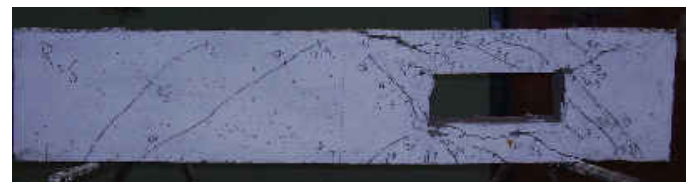

(7) Beam RO7

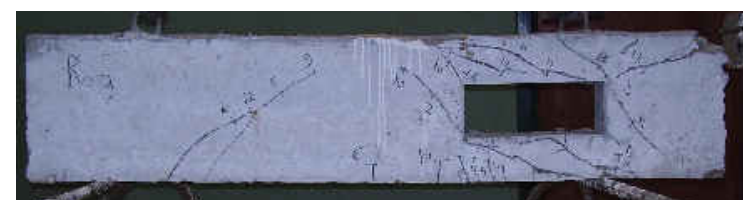

(9)Beam RO9

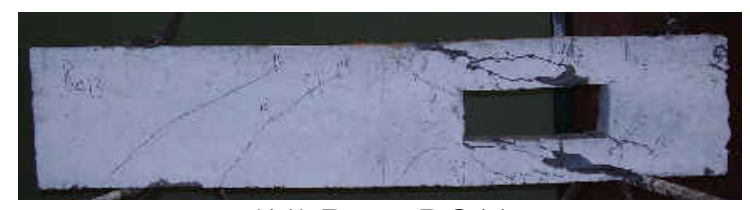

(11) Beam RO11

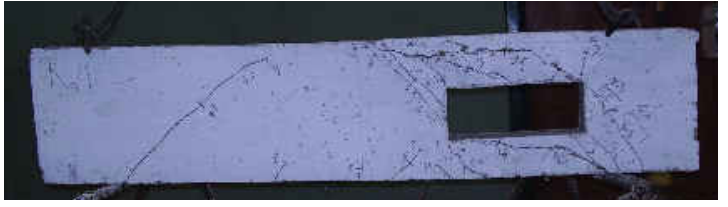

(4)Beam RO4

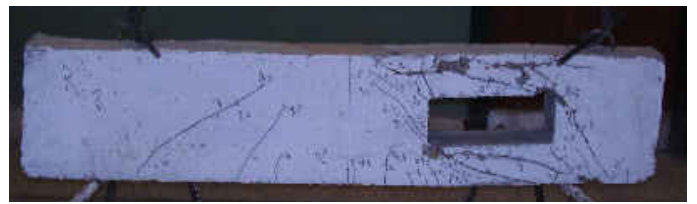

(6) Beam RO6

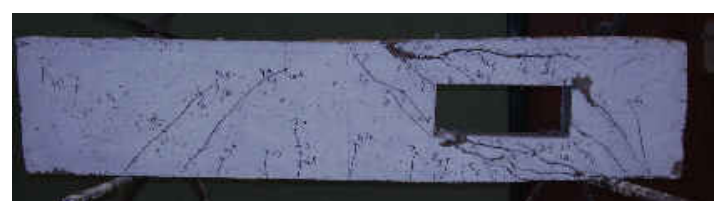

(8) Beam RO8

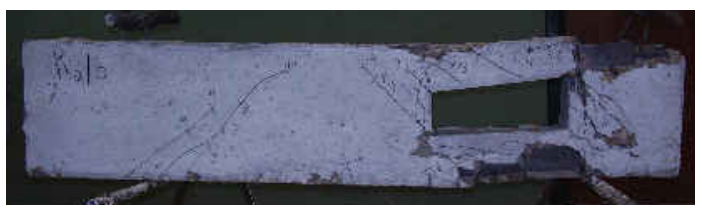

(10)Beam RO10

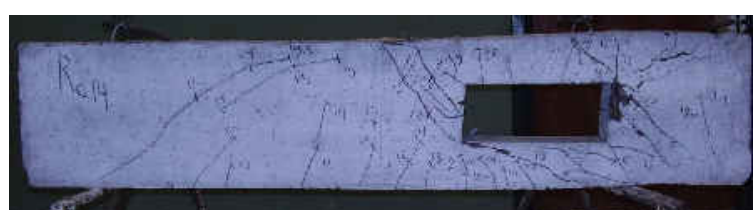

(12) Beam RO12

Fig. (3) Pattern of cracks of tested beams.

\section{ii- Loads and Deflections of Tested Beams at Both Cracking and Ultimate Level:}

Table (4) summarizes the obtained and recorded test results for the tested beams in form of cracking and ultimate load levels.

Where:

$\mathrm{f}_{\mathrm{c} \mathrm{u}} \quad=$ concrete grade.

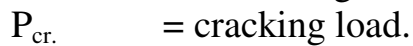

$\mathrm{P}_{\mathrm{u}} \mathrm{l} . \quad=$ ultimate load.

$\delta_{\mathrm{cr}} \quad=$ deflection at cracking load.

$\delta_{\text {mid }} \quad=$ mid span deflection at $90 \%$ of ultimate load.

S.F $\quad=$ shear failure.

$\delta_{\text {inn }} \quad=$ inner edge deflection at $90 \%$ of ultimate load.

S.F.O = shear failure at opening region.

$\delta_{\text {diff }}=$ difference between deflections of two opening edges at $90 \%$ of ultimate load 
Table (4) The Obtained Test Results for Tested Beams.

\begin{tabular}{|c|c|c|c|c|c|c|c|c|c|c|c|c|c|c|c|c|c|}
\hline \multirow{3}{*}{ 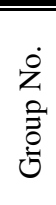 } & & \multirow{3}{*}{ 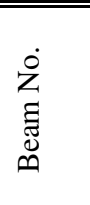 } & \multirow{3}{*}{ 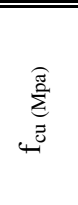 } & \multicolumn{7}{|c|}{$\begin{array}{c}\text { Internal Steel plates } \\
(\mathrm{cm})\end{array}$} & \multirow{3}{*}{ 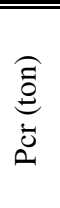 } & \multirow{3}{*}{ 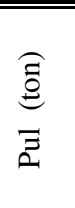 } & \multirow{3}{*}{$\frac{\widehat{\Xi}}{\stackrel{\Xi}{\Xi}}$} & \multirow{3}{*}{ 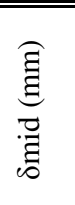 } & \multirow{3}{*}{$\underset{\Xi}{\widehat{\Xi}}$} & \multirow{3}{*}{ 氖 } & \multirow{3}{*}{ 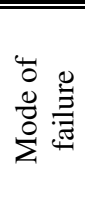 } \\
\hline & & & & \multicolumn{3}{|c|}{ horizontal } & \multicolumn{3}{|c|}{ vertical } & \multirow[t]{2}{*}{ Config. } & & & & & & & \\
\hline & & & & $\mathrm{L}_{\mathrm{h}}$ & $\mathrm{W}_{\mathrm{h}}$ & $\overline{t_{h}}$ & $\overline{\mathrm{L}_{\mathrm{v}}}$ & $\mathrm{W}_{\mathrm{v}}$ & $\overline{t_{v}}$ & & & & & & & & \\
\hline \multirow{2}{*}{\multicolumn{2}{|c|}{$\simeq$}} & $\overline{\text { SB1 }}$ & 30.3 & --- & --- & --- & -- & --- & $\begin{array}{l}-- \\
--\end{array}$ & -- & 5 & 15.9 & 0.77 & 2.95 & 2.94 & 0.79 & $\overline{S . F}$ \\
\hline & & $\mathrm{UO} 2$ & 32.5 & --- & --- & --- & --- & --- & --- & --- & 2.5 & 8.3 & 0.6 & 2.12 & 2.62 & 1.38 & S.F.O \\
\hline \multirow{3}{*}{\multicolumn{2}{|c|}{ 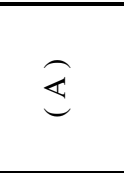 }} & RO3 & 28.5 & 50 & 5.0 & 0.3 & --- & --- & --- & Type1 & 2.5 & 11.6 & 0.47 & 4.16 & 4.34 & 2.7 & S.F.O \\
\hline & & RO4 & 29.1 & 50 & 5.0 & 0.2 & --- & --- & --- & Type1 & 2.5 & 9.8 & 0.52 & 3.11 & 3.21 & 1.96 & .F.O \\
\hline & & RO5 & 31.6 & 50 & 5.0 & 0.4 & --- & --- & --- & Type1 & 2.5 & 11.9 & 0.43 & 3.45 & 3.81 & 2.54 & S.F.O \\
\hline \multicolumn{2}{|c|}{$\widehat{\theta}$} & RO6 & 33.6 & 50 & 5.0 & 0.3 & 25 & 5.0 & 0.3 & Type2 & 2.5 & 11.6 & 0.55 & 4.46 & 4.93 & 3.4 & S.F.O \\
\hline \multirow{4}{*}{$\widehat{U}$} & \multirow{2}{*}{$\bar{U}$} & $\mathrm{RO} 7$ & 33.6 & 40 & 5.0 & 0.3 & --- & --- & --- & Type1 & 2.5 & 11.3 & 0.53 & 4.29 & 4.98 & 2.96 & S.F.O \\
\hline & & RO8 & 31.2 & 60 & 5.0 & 0.3 & --- & --- & --- & Type1 & 2.5 & 12 & 0.44 & 3.95 & 4.25 & 2.64 & S.F.O \\
\hline & \multirow{2}{*}{$\tilde{U}$} & RO9 & 29.8 & 40 & 5.0 & 0.3 & 25 & 5.0 & 0.3 & Type2 & 2.5 & 11 & 0.54 & 4.47 & 4.91 & 3.24 & S.F.O \\
\hline & & RO10 & 30 & 60 & 5.0 & 0.3 & 25 & 5.0 & 0.3 & Type2 & 2.5 & 12.3 & 0.48 & 3.81 & 4.1 & 2.6 & S.F.O \\
\hline & RO11 & 59.4 & 50 & 5.0 & 0.3 & --- & --- & $\begin{array}{l}-- \\
--\end{array}$ & Type1 & 5.5 & 17 & 1.14 & 4.88 & 5.13 & 3.16 & S.F.O \\
\hline & & RO12 & 77 & 50 & 5.0 & 0.3 & --- & --- & --- & Type1 & 6 & 19.5 & 1.2 & 6.27 & 7.54 & 3.69 & S.F.O \\
\hline
\end{tabular}

The relation between load and mid-span deflection for tested beams are presented in figure (4) through Figure (8).

\section{DISCUSSION OF TEST RESULTS}

The obtained test results were analysed to declare the effect of various included parameters taken in this work on strength, deformation as well as upon absorbed strain energy up to failure. These properties were measured by means cracking and ultimate load, cracking and ultimate defections as well as by toughness respectively. As follows:

\section{i- Effect of Steel Plates Thickness "Confinement Ratio"}

It is clear from Fig. (4) and Fig. (9), that increasing confinement ratio ( $\mu$ o \%) (Volume of steel plates / volume of confined concrete) has no effect on cracking load (Pcr.). Increasing confinement ratio increased the ultimate load, but increasing confinement ratio after a certain value has slight effect on ultimate load. Increasing confinement ratio from $0 \%$ to $1.85 \%$ increased the ultimate load by $18 \%$. Increasing confinement ratio from $1.85 \%$ to $2.78 \%$ increased the ultimate load by $22 \%$. Increasing confinement ratio from $2.78 \%$ to $3.7 \%$ increased the ultimate load by $3 \%$.

This may be related to that the failure occurred due to concrete crushing rather than yielding of steel plates. Thus the ACI limits on maximum shear appears to apply to beams with opening, provided $\mathrm{Vc}$ is calculated on basis of net section through the opening, this results was agreed with that given in ref. [6]. 


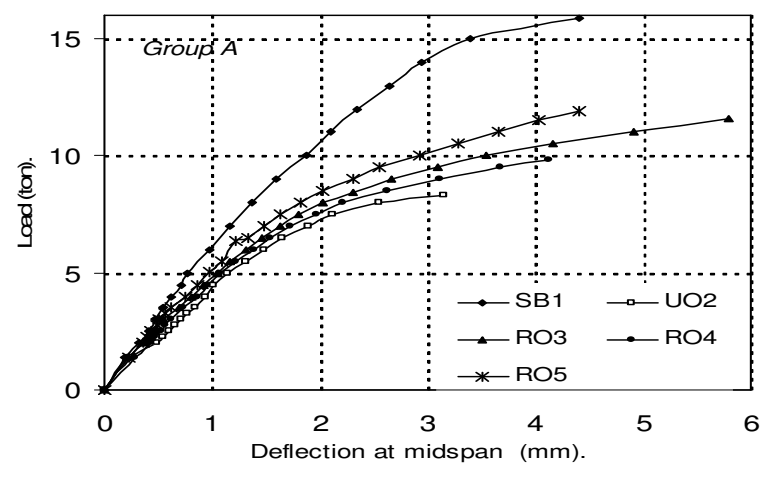

Fig. (4).

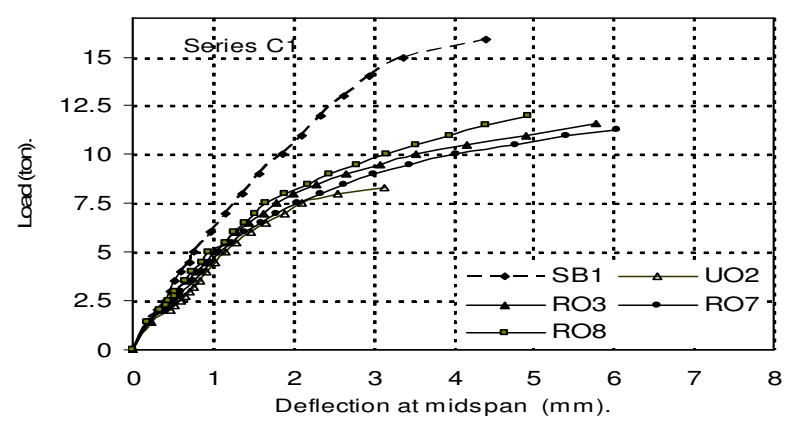

Fig.(6).

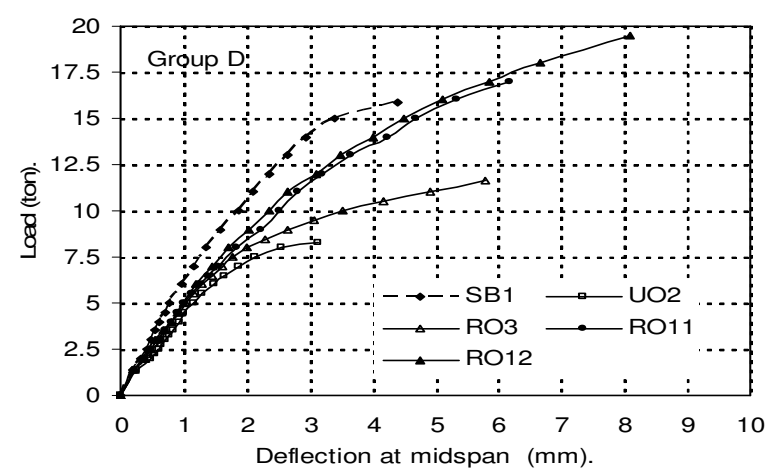

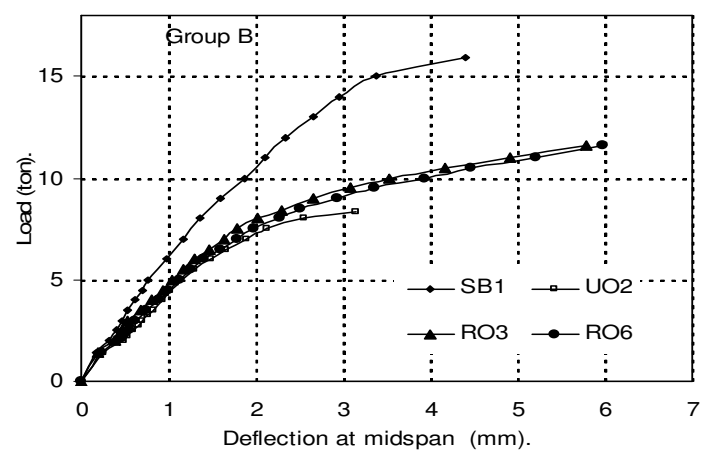

Fig. (5).

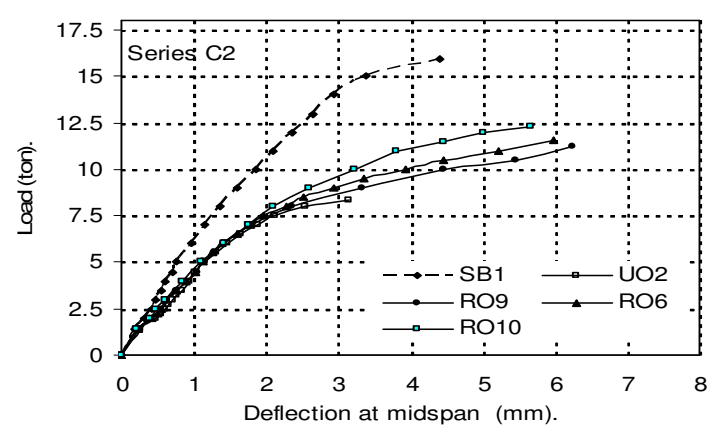

Fig.(7).

Fig.(8).

From Fig. (4) and Fig. (10), it can be seen that increasing confinement ratio ( $\mu$ o \%) decreased the deflection at cracking load $(\delta \mathrm{cr})$. This may be due to increasing of the stiffness at the opening region. It can be obvious from Fig. (11) that, due to load increasing, the deflection at mid span, inner edge deflection and difference between deflections of two opening edges for all strengthened beams at $90 \%$ of the ultimate load were more than those of beam having unstrengthened opening. Meanwhile, Fig. (4) indicates that at the same load, increasing confinement ratio ( $\mu$ o \%) decreased mid span deflection, inner edge deflection and the difference between deflections of two 
opening edges. This may be related to increasing beam stiffness at opening region. Increasing confinement ratio from $0 \%, 1.85 \%$ increased the mid span deflection, inner edge deflection and difference between deflections of two opening edges by $47 \%, 23$ $\%$ and $42 \%$ respectively. Increasing confinement ratio from $1.85 \%$ to $2.78 \%$ increased the mid span deflection, inner edge deflection and the difference between deflections of two opening edges by $49 \%, 43 \%$ and $54 \%$ respectively. Increasing confinement ratio from $2.78 \%$ to $3.7 \%$ decreased mid span deflection, inner edge deflection and the difference between deflections of two opening edges by $33 \%, 21 \%$ and $12 \%$ respectively.

Figure (12) indicates that confinement ratio has considerable effect on beam toughness. The toughness of beams was evaluated by means of area under loaddeflection diagram. In general, increasing confinement ratio increased beam toughness. However, due to deflection decreasing, beams having almost the same ultimate load the beam toughness decreased by increasing confinement ratio. Increasing confinement ratio from $0 \%$ to $1.85 \%$ increased beam toughness by $59 \%$. Increasing confinement ratio from $1.85 \%$ to $2.78 \%$ increased beam toughness by $116 \%$. Increasing confinement ratio from $2.78 \%$ to $3.7 \%$ decreased beam toughness by $64 \%$.

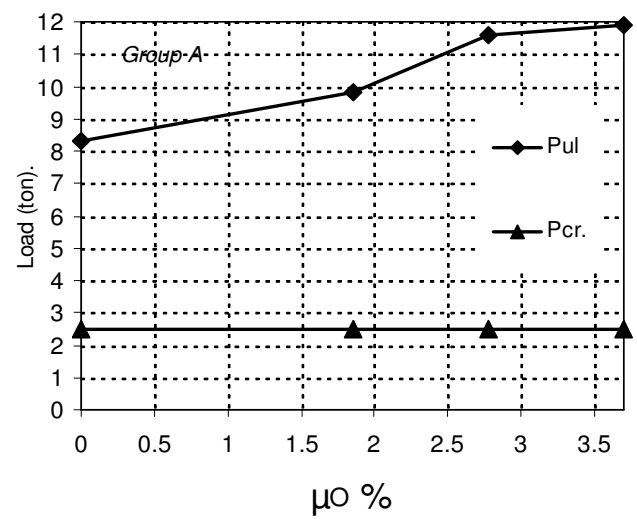

Fig. (9). Effect of confinement ratio on cracking and ultimate load

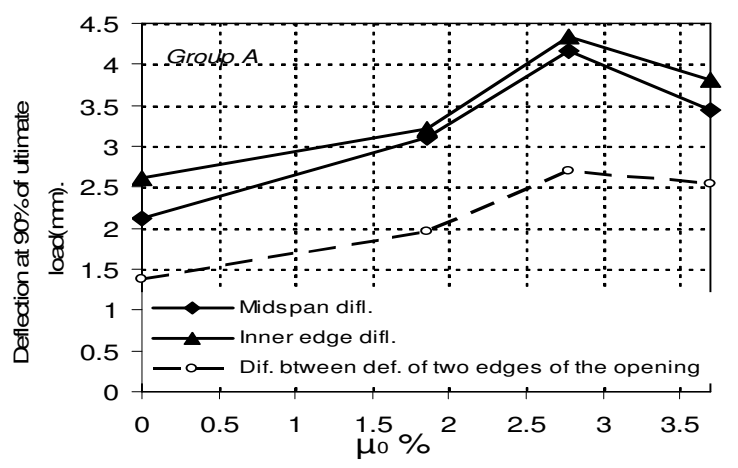

Fig. (11). Effect of confinement ratio on the deflections.

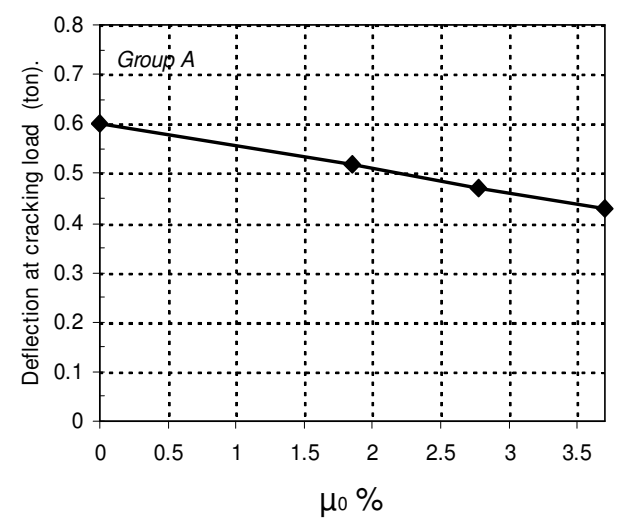

Fig.(10) Effect of confinement ratio on deflection at cracking load.

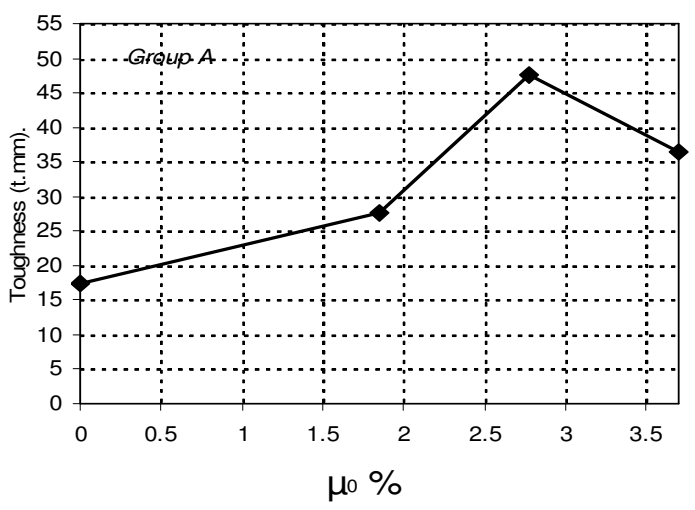

Fig. (12). Effect of confinement ratio on the beam toughness. 


\section{ii- Effect of Coniguration Type of Steel Plates}

Cracking load of beam having steel plate's configuration type 1 was the same one as for beam having steel plate's configuration type 2 . This may be attributed to the fact that the cracking load is mainly affected by concrete grade rather than by configuration type of steel plates.

The ultimate loads were not affected by steel plates configuration type (i.e. the vertical steel plates at the opening sides not affect the ultimate load value). The failure of two beams having different steel plates configurations was designated by what so called frame type failure "splitting of top and bottom chords of opening", consequently the effect of vertical steel plates on the ultimate load did not appear. See Fig. (5) and Fig. (13). For beams strengthened with any of two steel plates configuration types the ultimate load were $140 \%$ of beam having unstrengthened opening.

Figure (14) shows that, the deflection at cracking load for beam with steel plate's configuration type 2 is approximately similar to the deflection at cracking load for beam with steel plate's configuration type 1. It can be noticed from Fig. (15) that the deflection at mid span, inner edge deflection and the difference between deflections of two opening edges for beam with steel plate's configuration type 2 were slightly more than those for beam with steel plates configuration type 1 . This may be occurred due to that the presence of horizontal and vertical steel plates at opening corners without strong connection between them lead to reduction of the amount of concrete at these positions. In addition, the presence of vertical steel plates at the inside face of the horizontal steel plates vanish the bond between concrete and horizontal steel plates at these positions. All of these tend to make the opening corners to be weak and hence increase the deflections. The mid span deflections of beams having steel plates configurations type 1 and type 2 were $196 \%$ and $210 \%$ respectively of beam having unstrengthened opening, their inner edge deflections were $166 \%$ and $188 \%$ of beam having unstrengthened opening and their difference between deflections of two opening edges were $196 \%$ and $246 \%$ respectively of beam having unstrengthened opening.

Figure (16), indicates that, the toughness of beams strengthened with steel plates configuration type 1 or type 2 were greater than that of beam having unstrengthened opening. However, the toughness of beams with steel plate's configuration type 1 and type 2 were approximately similar to each other. The toughness of beam with steel plates configuration type 1 and type 2 were $275 \%$ and $278 \%$ respectively of beam having unstrengthened opening.

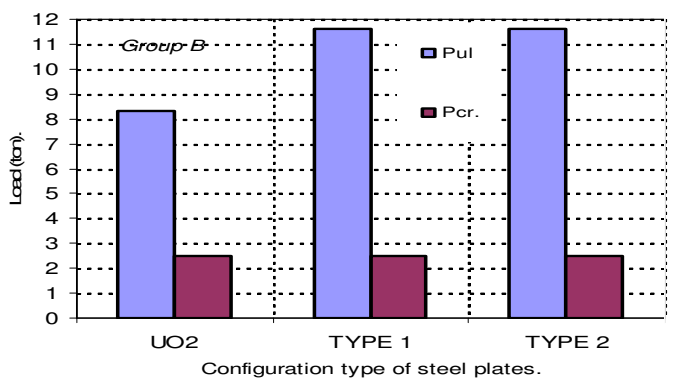

]Fig. (13). Effect of configuration type on cracking and ultimate load

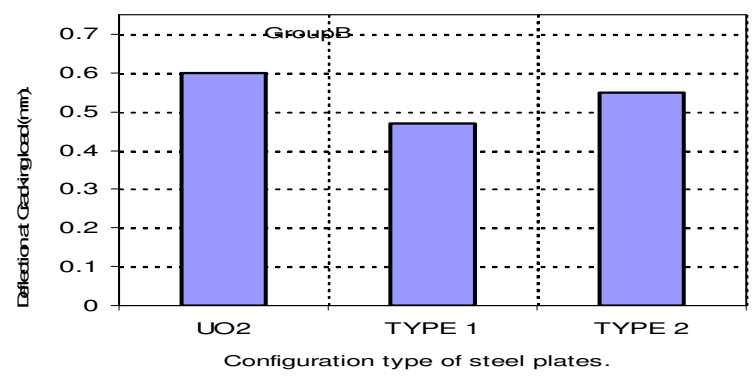

Fig. (14) Effect of configuration type on deflection at cracking load. 


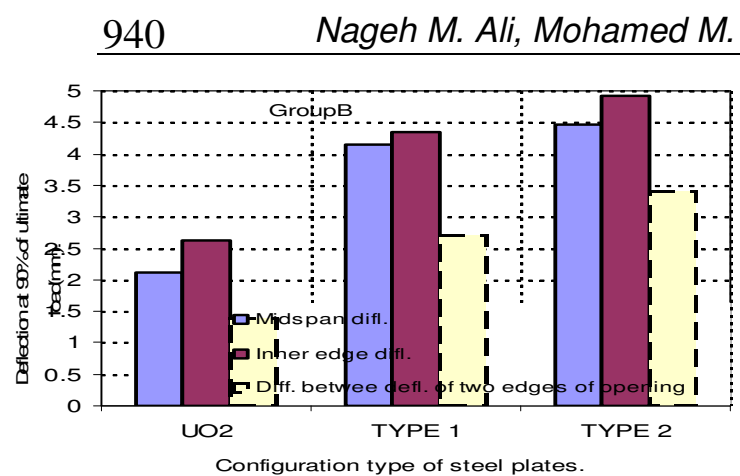

Fig. (15). Effect of configuration type on the deflections.

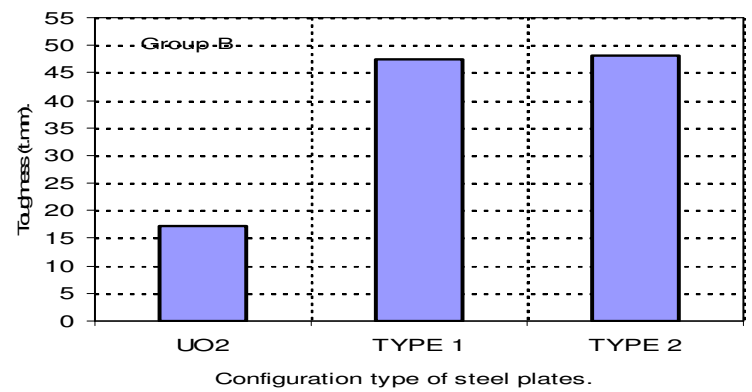

Fig. (16). Effect of confinement ratio on the beam toughness.

\section{iii- Effect of Horizontal Steel Plates Length}

From Fig.( 6, 7, 17 and 18), it was clear that for two types of steel plates configurations the cracking load was not affected by increasing the length of internal horizontal steel plates.

Increasing steel plate length, for both two types of steel plate configurations, increased the ultimate load. Increasing the length of steel plates more than $4 / 3$ of opening length increased the ultimate load slightly. This was because, as mentioned before, the failure occurred due to concrete crushing rather than yielding of steel plates, hence the force in steel plates did not increased more than certain value and so the anchorage length after this value was not required. The ultimate loads of beams having steel plate's configurations type 1 with horizontal steel plate's lengths of $0,1.33,1.67$ and 2.00 of opening length were $100 \%, 136 \%, 140 \%$ and $145 \%$ respectively of beam having unstrengthened opening. However, the ultimate loads of beams having steel plates configurations type 2 with horizontal steel plates lengths of $0,1.33,1.67$ and 2.00 of opening length were $100 \%, 135 \%, 140 \%$ and $148 \%$ respectively of beam having unstrengthened opening.

From Fig.(19) and (20), it can be observed that, increasing the length of internal steel plates, for both two types of steel plates configurations, decreased the deflection at cracking load.

It is obvious from Fig. (21) and (22), that all strengthened beams with any one of configuration types and with different lengths of steel plates showed that the mid span deflection, inner edge deflection and difference between deflections of two opening edges were greater than those of beam having unstrengthened opening. However, increasing the length of internal steel plates for beams with any type of steel plate configuration decreased mid span deflection, inner edge deflection and the difference between deflections of two opening edges. This may be due to the fact that the rigidity of opening corners usually increased by increasing the length of steel plates. The mid span deflection of strengthened beam with configuration type 1 having steel plates lengths of $1.33,1.67$ and 2 of opening length was $202 \%, 196 \%$ and $186 \%$ respectively of that unstrengthened opening, their inner edge deflections were $190 \%$, $166 \%$ and $162 \%$ respectively of beam having unstrengthened opening and their difference between deflections of two opening edges were 214\%, 196\% and $191 \%$ respectively of beam having unstrengthened opening. The mid span deflection of beam with configuration type 2 having steel plates lengths of 1.33, 1.67 and 2 of opening 
length was $218 \%, 210 \%$ and $180 \%$ respectively of that for beam having unstrengthened opening, their inner edge deflections were 195\%, 188\% and $156 \%$ respectively of beam having unstrengthened opening and their difference between deflections of two opening edges were $249 \%, 246 \%$ and $188 \%$ respectively of beam having unstrengthened opening.

From Figs. (23) and (24), it can be observed that, for two types of configurations, the toughness of all strengthened beams in this group was greater than those of beam having unstrengthened opening. While, increasing steel plates lengths than certain limit, for two types of configurations, decreased beam toughness. Beams with steel plates configurations type 1 having horizontal steel plates of lengths of 1.33 , 1.67 and 2.00 of opening length their toughness were 279\%, 275\% and $231 \%$ respectively of that for beams with unstrengthened opening. Meanwhile, beams with steel plates configurations type 2 having the same steel plates lengths their toughness was $283 \%, 278 \%$ and $275 \%$ respectively compared with that of beam having unstrengthened opening

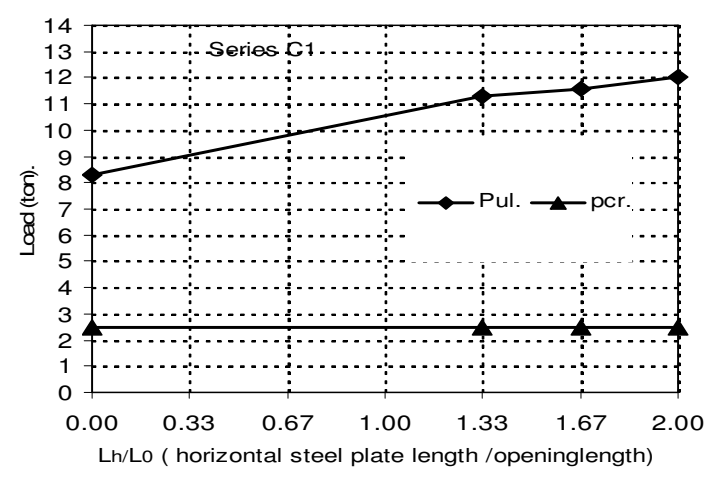

Fig. (17) Effect horiz. Steel pates length with config. Type 1 on cracking and ultimate load

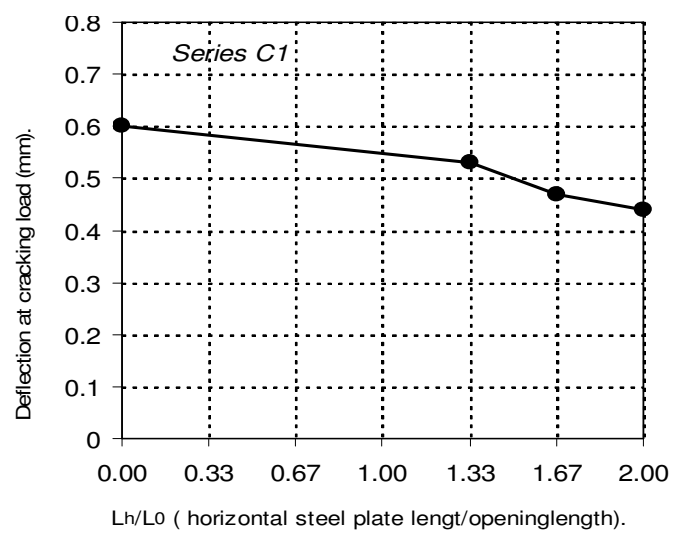

Fig. (19). Effect horiz. Steel pates length with config. Type 1 on deflection at cracking load.

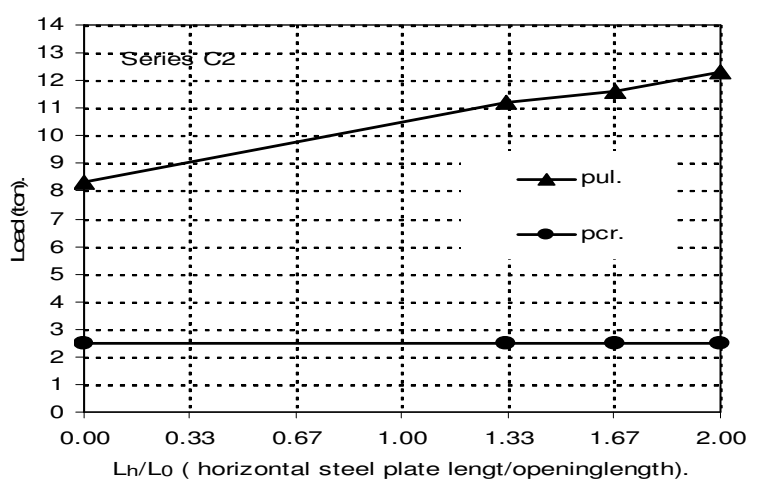

Fig. (18) Effect horiz. Steel pates length with config. Type 2 on cracking and ultimate load

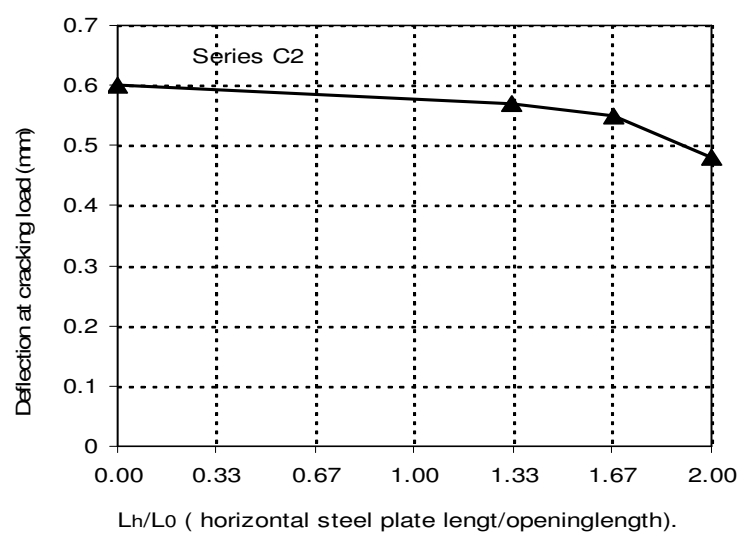

Fig. (20) Effect horiz. Steel pates length with config. Type 2 on deflection at cracking load. 


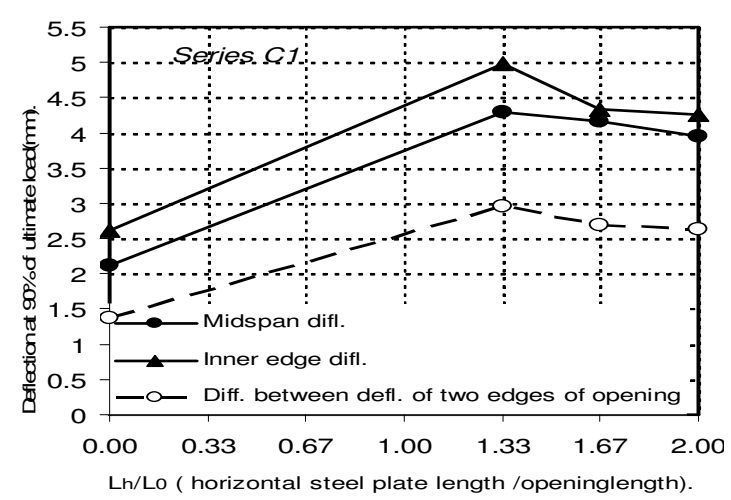

Fig. (21). Effect horiz. Steel pates length with config. Type 1 on deflections.

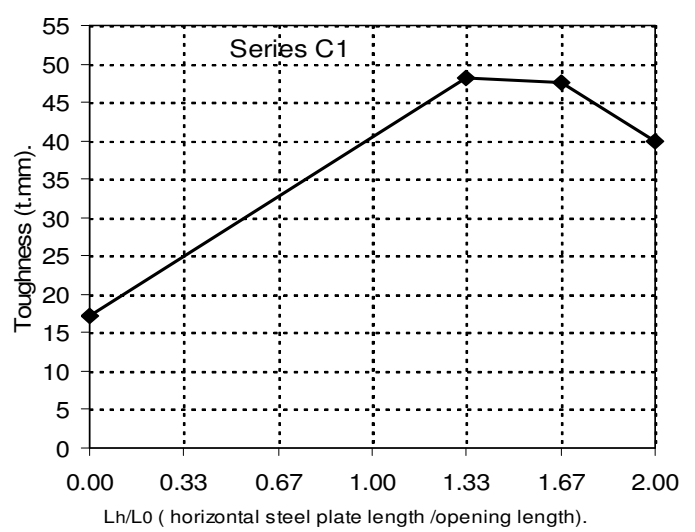

Fig. (23). Effect horiz. Steel pates length with config. Type 1 on toughness.

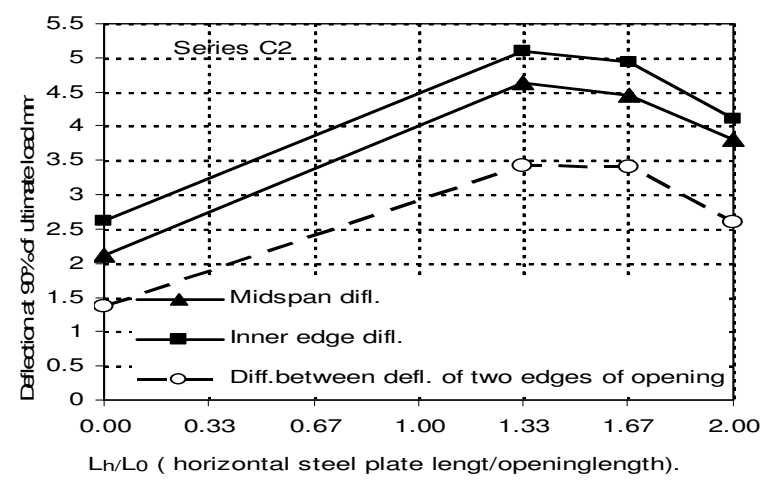

Fig. (22). Effect horiz. Steel pates length with config. Type 2 on deflections.

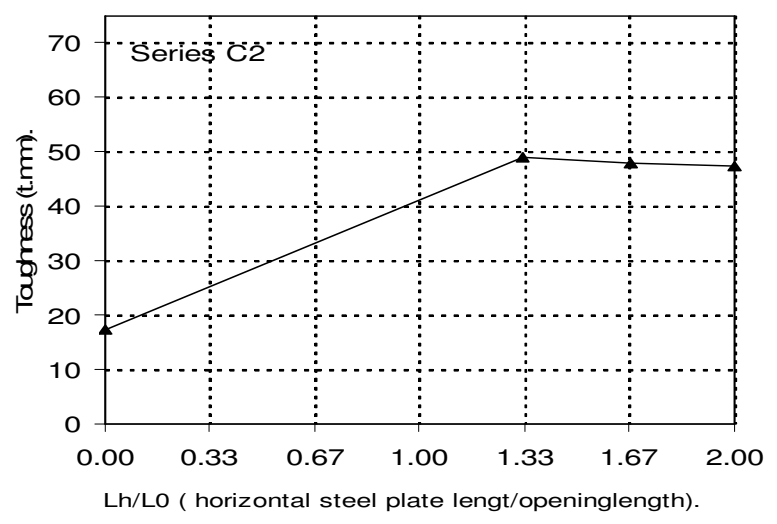

Fig. (24). Effect horiz. Steel pates length with config. Type 2 on toughness.

\section{iv- Effect of Concrete Grade}

It can be observed from Figs. (9) and Fig.(25), that the cracking load of strengthened beams increased by increasing grade of concrete. This may be due to increasing of compressive strength of concrete which accompanied by increasing its tensile strength. Beams with concrete grade of 28.5 MPa, 59.4 MPa and $77 \mathrm{MPa}$ the cracking loads were $100 \%, 220 \%$ and $240 \%$ respectively of beam with $32.5 \mathrm{MPa}$ as concrete grade. Increasing concrete grade considerably increased the ultimate load. This may be due to delaying concrete crushing in top and bottom chords of opening and hence promise to increase the load carried by horizontal steel plates and then increased the ultimate load. The ultimate loads of beams having opening with concrete grads of $28.5 \mathrm{MPa}, 59.4$ $\mathrm{MPa}$ and $77 \mathrm{MPa}$ were $140 \%, 205 \%$ and $235 \%$ respectively of beam having unstrengthened opening with concrete grade of $32.5 \mathrm{MPa}$.

It can be seen from Fig. (26) that increased concrete grade increased the deflection at cracking load. It can be obvious from Fig. (27) that, increasing concrete grade increased mid span deflection, inner edge deflection and the difference between deflections of two opening edges. The mid span deflections of beams with concrete 
grades of 28.5 MPa, 59.4 MPa and $77 \mathrm{MPa}$ were 196\%, 230\% and 296\% respectively of that for beam having unstrengthened opening with concrete grade of $32.5 \mathrm{MPa}$, their inner edge deflections were $166 \%, 196 \%$ and $288 \%$ respectively of beam having unstrengthened opening with concrete grade of $32.5 \mathrm{MPa}$ and their difference between deflections of two opening edges were $196 \%$, 229\% and $267 \%$ respectively of beam having unstrengthened opening with concrete grade of $32.5 \mathrm{MPa}$.

Figure (28) indicates that, increasing concrete grade considerably increased beam toughness.

Toughness of beams having concrete grade $28.5 \mathrm{MPa}, 59.4 \mathrm{MPa}$ and $77 \mathrm{MPa}$ were $275 \%, 379 \%$ and $595 \%$ respectively of beam having unstrengthened opening with concrete grade of $32.5 \mathrm{MPa}$.

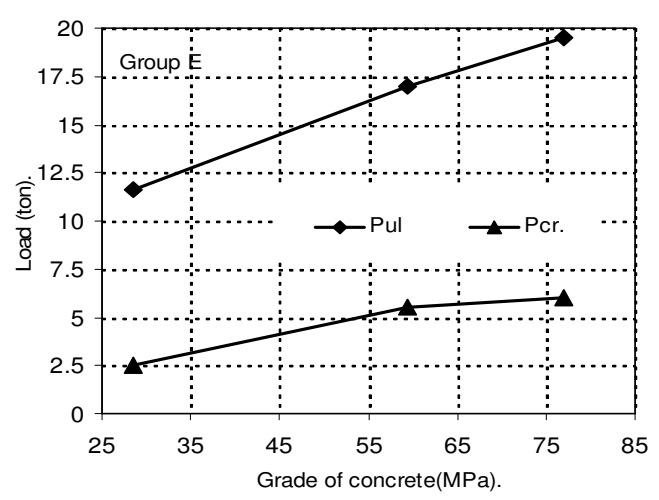

Fig. (25) Effect of concrete grade on cracking and ultimate load

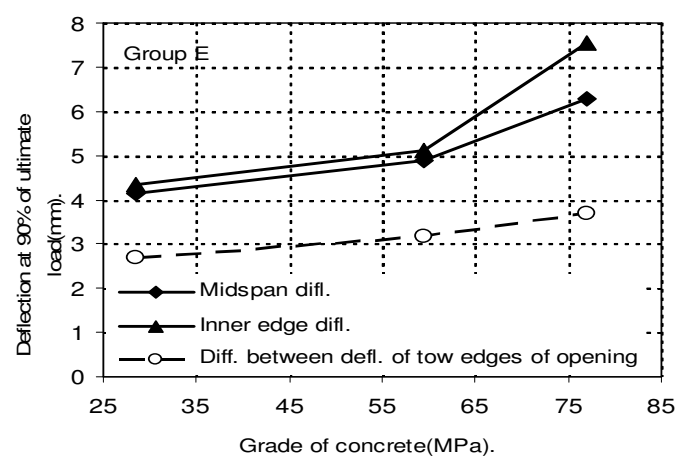

Fig. (27). Effect of concrete grade on deflections.

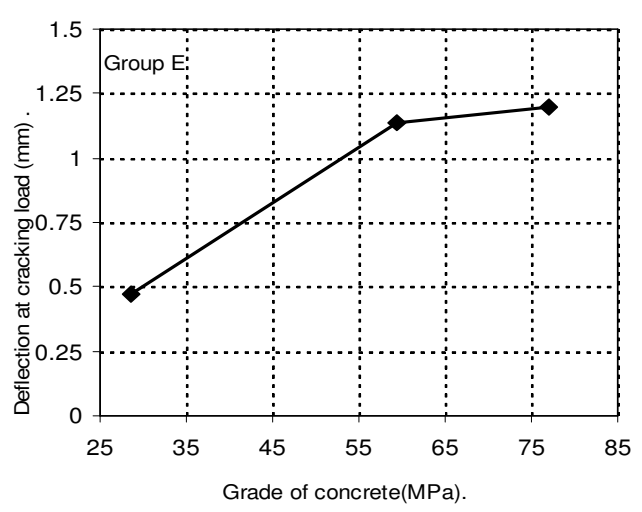

Fig. (26) Effect of concrete grade on deflection at cracking load.

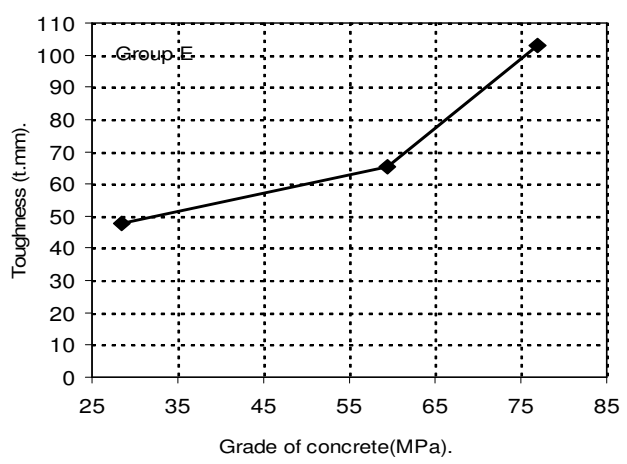

Fig. (28) Effect concrete grade on toughness.

\section{vi-Comparison of the Experimental Ultimate Load with that Predicted In Reference [9]:}

To compare the experimental results with the predicted ultimate load using some equations found in the literature, the ultimate expected theoretical load for tested beams was estimated using the following equation proposed by Abdel-Shafy [9]. 


$$
\mathrm{P}_{\mathrm{u}}=0.0083
$$

$$
\frac{\mu^{0.085} \mathrm{f}_{\mathrm{c}}^{0.3} \mathrm{~A}_{\mathrm{t}+\mathrm{b}}}{\left(\frac{\mathrm{d}_{0}}{\mathrm{~d}}\right)^{0.7}\left(\frac{\mathrm{l}_{0}}{\mathrm{a}}\right)^{0.72}\left(\frac{\mathrm{S}_{0}}{\mathrm{a}}\right)^{0.58}\left(\frac{\mathrm{a}}{\mathrm{d}}\right)^{0.5}}
$$

Where;

$\mathrm{P}_{\mathrm{u}}=$ The predicted ultimate load in (ton).

$\mu=\rho+2 \mu \mathrm{t}+2 \mu \mathrm{b}$

$\rho=$ Main reinforcement ratio.

$\mu_{\mathrm{t}}=$ Horizontal reinforcement ratio around opening in top chord $\left(\mathrm{A}_{\mathrm{st}} / \mathrm{A}_{\mathrm{ct}}\right)$.

$\mu_{b}=$ Horizontal reinforcement ratio around opening in bottom chord $\left(\mathrm{A}_{\mathrm{sb}} / \mathrm{A}_{\mathrm{cb}}\right)$.

$\mathrm{A}_{\mathrm{st}}=$ Area of horizontal reinforcement around opening in top chord $\left(\mathrm{cm}^{2}\right)$.

Ast $=$ Area of horizontal reinforcement around opening in bottom chord $\left(\mathrm{cm}^{2}\right)$.

$\mathrm{A}_{\mathrm{ct}}=$ Concrete area of top chord $\left(\mathrm{cm}^{2}\right)$.

$\mathrm{A}_{\mathrm{cb}}=$ Concrete area of bottom chord $\left(\mathrm{cm}^{2}\right)$.

$\mathrm{A}_{\mathrm{t}+\mathrm{b}}=\Sigma$ of concrete area of top and bottom chords $\left(\mathrm{cm}^{2}\right)$.

$\mathrm{d}=$ Depth of beam $(\mathrm{cm})$.

$\mathrm{a}=$ Shear span length of beam $(\mathrm{cm})$.

$\mathrm{d}_{0}=$ Opening depth $(\mathrm{cm})$.

$\mathrm{S}_{0}=$ Distance between nearest support and center of opening $(\mathrm{cm})$.

$\mathrm{L}_{0}=$ Opening length $(\mathrm{cm})$.

Figure (29), shows the relation between the experimental ultimate load and the predicted ultimate load for the tested beams by Abdel-Shafy equation [9]. It can be notice that Abdel-Shafy equation satisfactory for predicting of the ultimate load for normal strength R.C beams having rectangular web opening and strengthened internally by using steel plates, but it is not satisfactory for the same beams with high strength concrete grade.

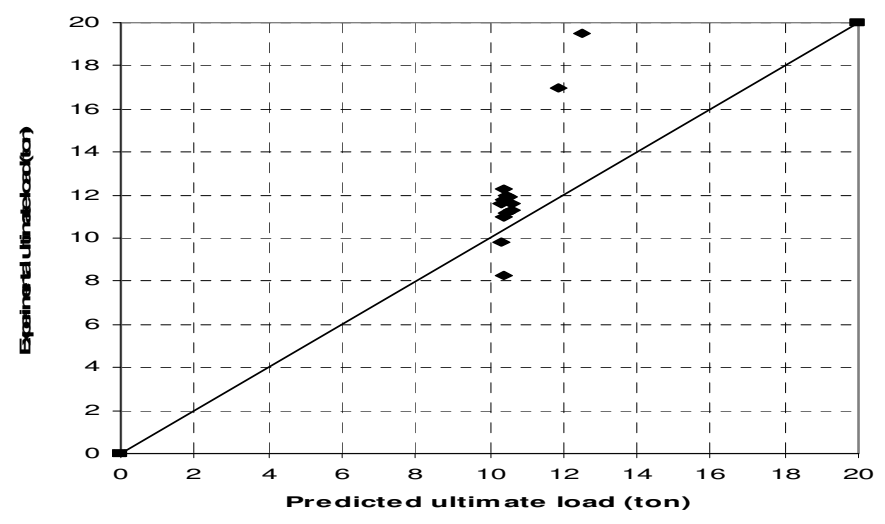

Fig. (29), Comparison between experimental ultimate loads and predicted ultimate load based on Abdel-Shafy equation [9].

\section{CONCLUSIONS}

The following conclusions may be drawn from the experimental investigation of R.C Beams having rectangular openings through the web at shear zone and strengthened internally by using steel plates: 
1. The mode of failure of beams with a/d $=2.4$ and having opening in shear zone with height 0.4 of the beam depth and with length of 2.5 of its depth is usually of shear failure at opening region.

2. The presence of an opening in shear zone of R.C concrete beam with height of 0.4 the beam depth and with length of 2.5 its depth significantly decreases its cracking and ultimate load. The ultimate loads of beams with openings may be reduced by about $50 \%$ compared to similar beam without openings.

3. The cracking load of beams having opening in shear zone strengthened internally with steel plates is not affected by any of steel plates thickness, steel plates configurations type, and horizontal steel plates length.

4. Increasing the thickness of steel plates around the shear zone openings increased the ultimate loads up to limited value depending on concrete grade beyond which the ultimate load may be constant or slightly decreased.

5. Beams having rectangular opening in shear zone strengthened with internal steel plates with configuration type 1 or type 2 have the same ultimate load.

6. The ultimate load of beams having rectangular opening in shear zone strengthened internally with steel plates with configurations used in this research slightly increased by increasing the length of horizontal steel plates.

7. Increasing the thickness of steel plates and the length of horizontal steel plates decreases mid span deflection, inner edge deflection and difference between deflections of two opening edges.

8. Mid span deflection, inner edge deflection and difference between deflections of two opening edges for beams with steel plates configuration type 2 were greater than those for beams with steel plate's configuration Type 1 .

9. Increasing concrete grade of beams having rectangular opening in shear zone strengthened with internally steel plates considerably decreased mid span deflection, inner edge deflection and the difference between deflections of two opening edges.

10. The presence of an opening in shear zone of R.C concrete beam with height of 0.4 the beam depth and with length of 2.5 its depth usually reduces beam toughness by about $60 \%$ compared to similar beam without openings.

11. Increasing the thickness of steel plates, the length of horizontal steel plates around the opening decreased beam toughness.

12. Increasing concrete grade of beams having rectangular opening in shear zone strengthened with internally steel plates considerably increased beam toughness.

13. Abdel-Shafy equation [9] can be satisfactorily used only for predicting the ultimate load for normal strength R.C beams rather than for high strength R.C beams having rectangular web opening and strengthened internally by using steel plates.

\section{REFERENCES}

[1] ACI Committee 318, Building Code Requirements for R.C. (ACI-89), American Concrete Institute, Detroit, 1995.

[2] Egyptian code for design and construction of R.C structures, edition 2006.

[3] Hemdan Okasha "Structural Behaviour of R. C. Beams Having Openings 
Strengthen by Using CFRP Sheets.” M. Sc. Thesis, Assuit University, Assuit, Egypt, 2000.

[4] Mansur, Mohammed A., Tan, K. H.; and Lee, S. L; "Design method for Reinforced Concrete Beams with large Openings." ACI structural Journal, pp.517-524, July-August 1985.

[5] Mansur, Mohammed, "Effect of Openings on the Behaviour and Strength of R.C. Beams in Shear" Elsiver Science Ltd pp. 478-486, 1998.

[6] Mansur, Mohammed A., Tan, K. H.; and Weng Wei; "Design of Reinforced Concrete Beams with circular Openings " ACI structural Journal, Proceedings Vol. 99, No. 3, pp. 407-415, May- June 2001.

[7] Nassef. M. B.; Ibrahim, S.; and El-Uhazouly, "Behaviour of Reinforced concrete Beams with Openings in Shear Zone", ESEC Proceedings, V.3, Cairo University, Giza, Egypt, 1985.

[8] Neff, C.; Schnellenbach-Held, M.; Daus, S“ RC Beams with One Large Rectangular Opening "-Experimental Investigations- Darmstadt Concrete 17 (2002). http://www.darmstadt-concrete.de/2002/beams.html

[9] Zainab E. Abdel-Shafy et. al "Static Behaviour of High Strength Reinforced Concrete Beams with Large Web Opening in Negative Moment". Ph.D. Thesis, Assuit University, Assuit, Egypt, 2007.

\section{كفاءة التقوية الاخلية للكمرات الخرسانية المسلحة ذات الفتحات المستطيلة فى منطقة القص باستخرام الواح الصلب}

ظهرت فى الا عمال الانثائية الحاجة الى عمل فتحات باشكال مختلفة خلال اعصاب الكمرات الخرسانية المسلحة لاستخدامها كمرات للتوصيلات الكهبية والميكانيكية وخلافه. ان وجود هذه الفتحات يؤثر بالسلب على مقاومة وصلابة هذه الكمرات، مما دعا العديد من الباحثين لدراسة السلوك الانثائى لحئ للكمرات الخرسانية المسلحة ذات الفتحات لتحديد مدى كفاءتها وكيفية تقويتها وتنليحتها لدقاومة الاجهادات المنولدة فيها نتيجة الاحمال الواقعة عليها. وقد توصل الباحثُن فى هذا المجال الى نتائج طيبة من حيث قدرتهم علي تحديد الثكل والمقاس المثالي للفتحة وكذللك الموقع المناسب لهذه الفتحات سواء بالنسبة لموضعها في الاتجاه الطولي لمحور الكمرة او لهاو خلال عمقها. كذلك توصل الباحثون الي انسب الاساليب لكيفية تسليح وتقوية هذه الفتحات.

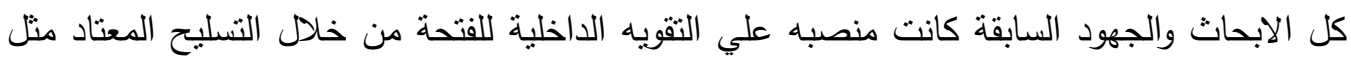
الكانات اعلي واسفل الفتحة وكذلك علي جانبيها بالاضافة الي الحديد المكسح علي جانبي الفتحة وايضا لهابه

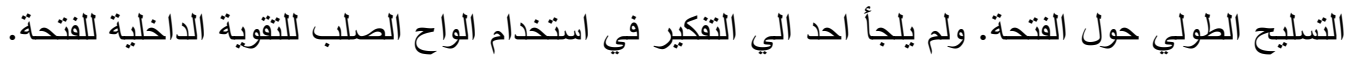
البحث القائم بين ايدينا يحاول دراسة ناثير استخدام الواح الصلب في تقوية منطقة الفتحات علي

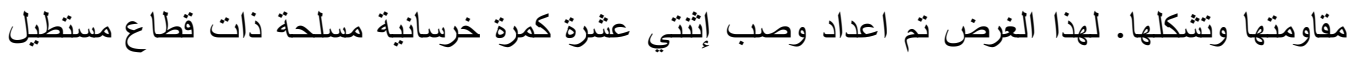

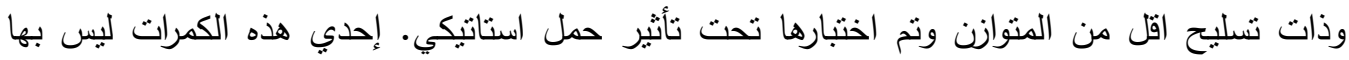


فتحات وباقي الكمرات بكل واحدة منهم فتحة واحدة مسنطيلة في عصبها في منطقة القص، عشر كمرات

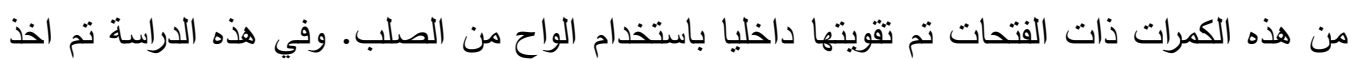

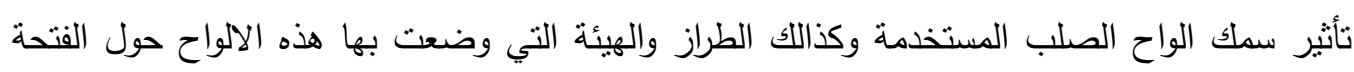

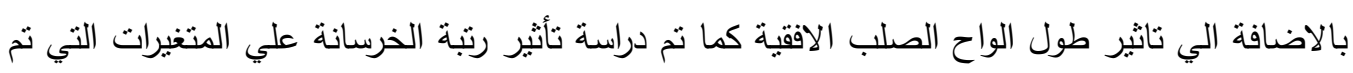

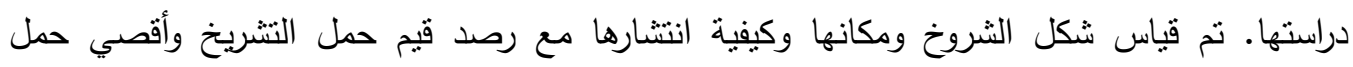

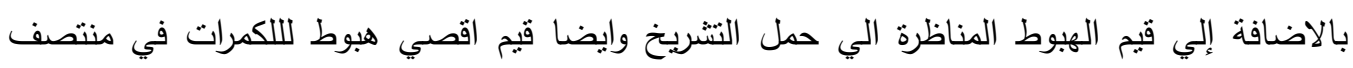

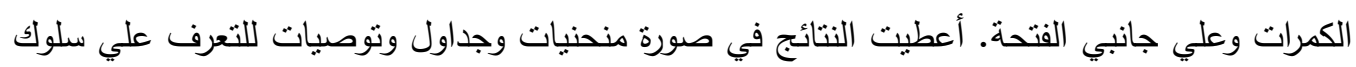

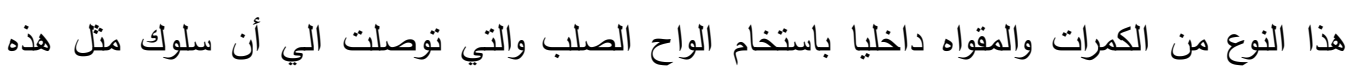

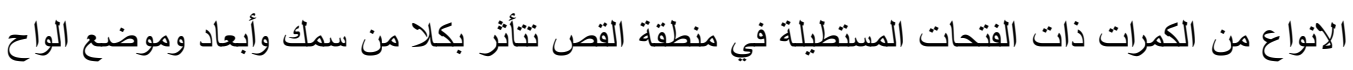
الصلب المستخدمة حول الفتحة سواء رأسيا أو أفقيا بالاضافة الي رنبة الخرسانة المستخدمة. 